\title{
Studies on erythrocyte membranes of patients with Huntington's disease
}

\author{
THOMAS MAR DUBBELMAN, A DR IA A N DE BRUIJNE, \\ J OH N Y VAN STEVENINCK, A N GEORGE W BRUYN \\ From the Sylvius Laboratories, Laboratory for Medical Chemistry, and the Department of Neurology, \\ Academic Hospital, Leiden, The Netherlands
}

S U M MARY Several red cell membrane properties and activities of membrane-bound enzymes were investigated in blood samples of patients with Huntington's disease. $\left(\mathrm{Na}^{+}+\mathrm{K}^{+}\right) \mathrm{ATPase}$ activity and cell deformability appeared to be normal, in contradiction to preceding reports from other laboratories. With other techniques sensitive to relatively small changes in membrane structure, no abnormalities were found in Huntington's disease red cell membranes. These investigations do not support the concept that a generalised membrane abnormality is present in Huntington's disease.

In recent studies it has been postulated that Huntington's disease (HD) is associated with a diffuse, generalised membrane defect. This concept is based mainly on the apparently abnormal surface properties of erythrocytes and skin fibroblasts in Huntington's disease, including altered electron spin resonance parameters, ${ }^{12}$ increased $\left(\mathrm{Na}^{+}+\mathrm{K}^{+}\right)$ATPase activity, ${ }^{3}$ decreased cell deformability ${ }^{2}$ and an increased number of s'omatocytes $^{4}$ in erythrocyte studies, and anomalous cellular proliferation and fluorescence spectroscopy in studies with fibroblasts. ${ }^{56}$ The altered election spin resonance parameters and the increased $\left(\mathrm{Na}^{+}+\mathrm{K}^{+}\right)$ATPase activity of the red blood cell membrane have been interpreted as an alteration in conformation or organisation of membrane proteins (or both) in Huntington's disease. Demonstration of such generalised membrane defects would be important both for further studies on the biochemical basis of the disease and for the development of diagnostic tests. Therefore some aspects of red blood cell membrane structure and function were investigated in detail. These studies included the measurement of membrane-bound $\left(\mathrm{Na}^{+}+\mathrm{K}^{+}\right)$ATPase activity and red cell deformability, both claimed to be ab-

Address for reprint requests: J van Steveninck, Laboratory for Medical Chemistry, Wassenaarseweg 72, 2333 AL Leiden, The Netherlands.

Accepted 10 March 1981 normal in Huntington's disease. Other experiments concerned membrane properties which might be sensitive to relatively small changes in membrane conformation and organisation. It will be shown that these investigations do not support the concept of a generalised membrane defect in Huntington's disease.

\section{Materials and methods}

Heparinised blood of patients with Huntington's disease and of normal, healthy donors was stored at $4^{\circ} \mathrm{C}$ and centrifuged $0.5-2$ hours after collection. The red blood cells were washed three times in buffered, isotonic $\mathrm{NaCl}$ solution $(154 \mathrm{mM} \mathrm{NaCl}, 9.6 \mathrm{mM}$ $\mathrm{Na}_{2} \mathrm{HPO}_{4}$ and $1.5 \mathrm{mM} \mathrm{NaH} \mathrm{PO}_{4}$ ) and resuspended in the same medium. This red blood cell suspension was used the same day. The diagnosis of Huntington's disease in the group of patients was beyond doubt, based on the clinical history and a detailed pedigree analysis. Five patients received drug therapy. In the experimental results no differences were observed between treated and untreated patients. The control group had the same sex and age distribution.

Red cell deformability measurements were carried out in a Brookfield cone-plate viscosimeter, as described by Weed et al. ${ }^{7}$ Hypertonic cryohaemolysis was determined as described by Dubbelman et al ${ }^{8}$ in 0.9 and $1.0 \mathrm{M} \mathrm{NaCl}$. Dielectric breakdown of red blood cells was measured as described by Riemann et al. ${ }^{9}$ After subjecting the cells to electric shock they were incubated for $30 \mathrm{~min}$ at 0 or $37^{\circ} \mathrm{C}$, before measuring haemoglobin release. 
Haemoglobin-free red cell membranes were prepared according to the method of Fairbanks et al. ${ }^{10}$ Spectrin was extracted as described by Bennett and Branton $^{11}$ and purified by precipitation at $\mathrm{pH} 5 \cdot 1$. Sodium dodecyl-sulfate polyacrylamide gel electrophoresis of membrane proteins was performed according to Fairbanks et al,10 with subsequent staining of protein bands with Coomassie Brilliant Blue and of glycoproteins with the periodic acid-Schiff procedure. Isoelectric focusing of spectrin was done on polyacrylamide gels according to Boivin and Galand. ${ }^{12}\left(\mathrm{Na}^{+}+\mathrm{K}^{+}\right)$ATPase and $\mathrm{Mg}^{2+-}$ ATPase were measured as described by Hodson and Pleasure. ${ }^{13}$

Phosphorylation of membrane proteins was studied essentially as described by Hosey and Tao. ${ }^{14}$ The assay mixture contained $10 \mathrm{mM} \mathrm{MgCl}_{2}, 0.2 \mathrm{mM}$ ATP, $20 \mathrm{mM}$ TRIS/ $/ \mathrm{HCl} \mathrm{pH} 8 \cdot 0$ and TRIS/HCl-washed, freeze-thawed ghosts $(0 \cdot 3-0 \cdot 4 \mathrm{mg}$ protein). The final volume was $0.2 \mathrm{ml}$. When present, the cAMP concentration was $2 \mu \mathrm{M}$. After $30 \mathrm{~min}$ the incubation was stopped by adding electrophoresis buffer with $1 \%$ SDS and heating the mixture at $70^{\circ} \mathrm{C}$ for $10 \mathrm{~min}$. Electrophoresis was done with gels, cross-linked by N,N-diallyltartardiamide as described by Anker ${ }^{15}$ After fixation and staining, the band $1+2,3$ and 4.5 were cut out and dissolved in $2 \%$ periodic acid. Subsequent radioactivity analysis was done by liquid scintillation counting.

Fluorescence of membrane-bound 8-anilino-1-naphthalene sulfonic acid (ANS) and perylene was measured by the following procedure. A mixture of $100 \mu 1$ packed ghosts, $2 \mathrm{ml} 0.25 \% \mathrm{NaCl}$ and either $20 \mu \mathrm{l}$ ANS solution $(1 \mathrm{mg} / \mathrm{ml}$ alcohol) or $20 \mu \mathrm{l}$ perylene (0.52 $\mathrm{mg} / \mathrm{ml}$ acetone) was incubated at a constant temperature between $20-60^{\circ} \mathrm{C}$. After incubation for $10 \mathrm{~min}$ at this temperature the mixture was incubated for another $10 \mathrm{~min}$ in melting ice. Subsequently fluorescence was measured at $0^{\circ} \mathrm{C}$, utilising an Aminco-Bowman spectrophotofluorometer with constant-temperature cell compartment.

\section{Results}

The deformability of red blood cells of HD patients is shown in fig 1 . As the viscosity of erythrocyte suspensions with a haematocrit in excess of 60 is completely determined by the visco-elastic properties of the cell membrane, ${ }^{16}$ the plots reflect directly the deformability of the cells at different shear rates. These results, as well as the results obtained with blood samples of three other patients with Huntington's disease, were in the normal range (shaded area in fig 1).

Hypertonic cryohaemolysis, measured after preincubation at $25,30,40$ and $50^{\circ} \mathrm{C}$ in 0.9 and $1.0 \% \mathrm{NaCl}$, is shown in table 1 . No significant differences between Huntington's disease and normal blood samples were observed.

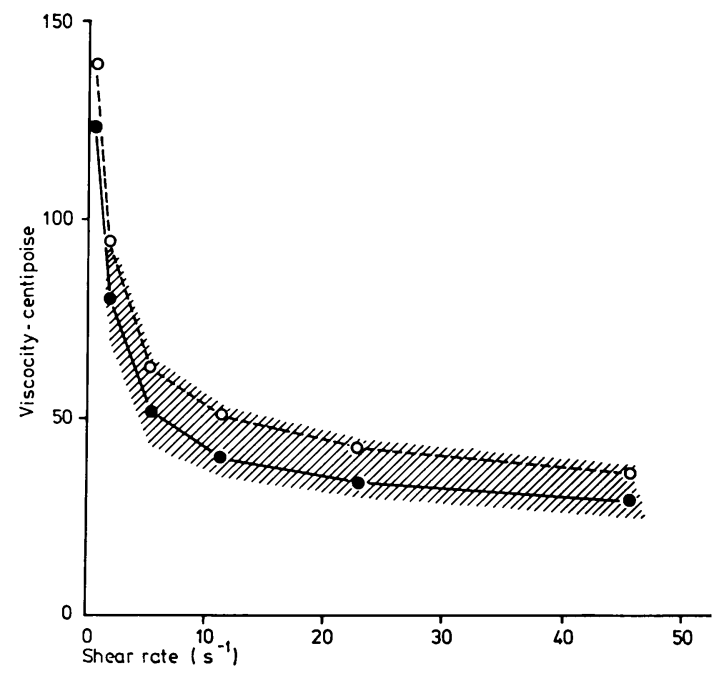

Fig 1 Viscosity of two samples of $H D$ red blood cells at different shear rates. Haematocrit: $80 \%$. The shaded area represents the normal range, as determined on 36 blood samples of healthy controls.

Dielectric haemolysis of HD red blood cells is shown in fig 2. With 10 different Huntington's disease blood samples the results were within the normal range. Fluorescence of membrane-bound ANS and perylene, measured at $0^{\circ} \mathrm{C}$, is strongly dependent on the preincubation temperature. This is shown in fig 3. Fluorescence measured on six normal and six Huntington's disease blood samples revealed no differences between the two groups, either in the excitation and emission

Table 1 Percent haemolysis of $0.2 \%$ erythrocyte suspensions preincubated at $25,30,40$ and $50^{\circ} \mathrm{C}$ in 0.9 and $1.0 \mathrm{M} \mathrm{NaCl}$ during $10 \mathrm{~min}$ and subsequently for $10 \mathrm{~min}$ in melting ice

\begin{tabular}{|c|c|c|c|c|}
\hline \multirow{2}{*}{$\begin{array}{l}\text { Preincubation } \\
\text { temperature }{ }^{\circ} \mathrm{C}\end{array}$} & \multicolumn{2}{|l|}{$0.9 \mathrm{M} \mathrm{NaCl}$} & \multicolumn{2}{|l|}{$1.0 \mathrm{M} \mathrm{NaCl}$} \\
\hline & Controls & Patients & Controls & Patients \\
\hline $\begin{array}{l}25 \\
30 \\
40 \\
50\end{array}$ & $\begin{array}{l}16 \cdot 6 \pm 5 \cdot 1(n=10) \\
24 \cdot 3 \pm 7 \cdot 6(n=10) \\
22 \cdot 7 \pm 8 \cdot 0(n=10) \\
14 \cdot 3 \pm 4 \cdot 2(n=10)\end{array}$ & $\begin{array}{l}20 \cdot 2 \pm 6 \cdot 6(n=6) \\
25 \cdot 7 \pm 9 \cdot 2(n=6) \\
22 \cdot 4 \pm 6 \cdot 6(n=6) \\
17 \cdot 9 \pm 8 \cdot 4(n=6)\end{array}$ & $\begin{array}{l}36 \cdot 5 \pm 8 \cdot 5(n=13) \\
47 \cdot 7 \pm 8 \cdot 1(n=13) \\
34 \cdot 3 \pm 8 \cdot 6(n=13) \\
14 \cdot 8 \pm 3 \cdot 8(n=13)\end{array}$ & $\begin{array}{l}40 \cdot 8 \pm 8 \cdot 3(n=9) \\
50 \cdot 3 \pm 7 \cdot 2(n=9) \\
38 \cdot 9 \pm 11 \cdot 7(n=9) \\
20 \cdot 5 \pm 7 \cdot 3(n=9)\end{array}$ \\
\hline
\end{tabular}




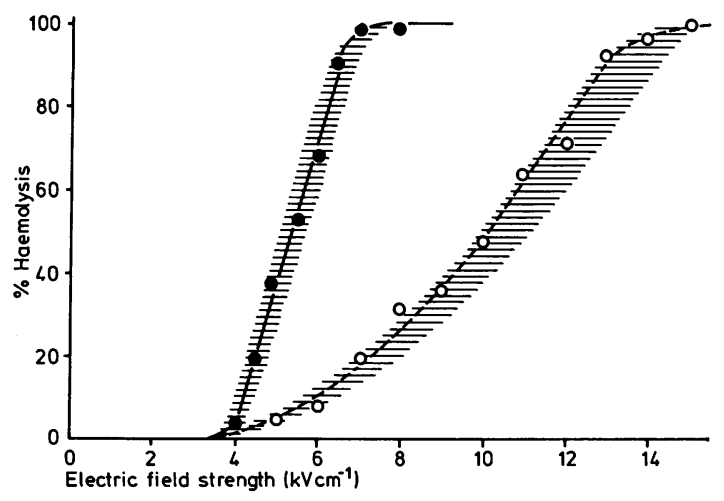

Fig 2 Hemolysis of HD red blood cells as a function of the electric field strength at a pulse length of $5 \mu \mathrm{s}$ - $: 0^{\circ} \mathrm{C} ; \mathrm{O}-\mathrm{O}: 37^{\circ} \mathrm{C}$. The shaded area represents the normal range.

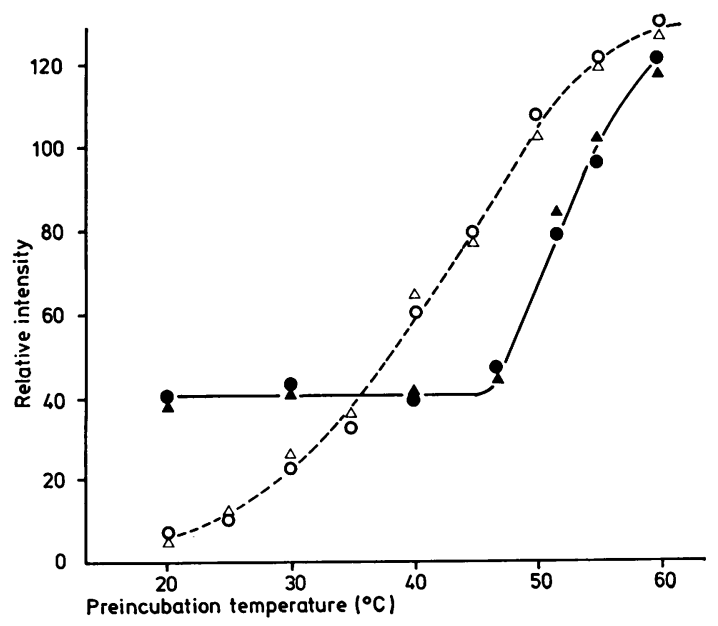

Fig 3 Relative fluorescence intensity of membranebound ANS (closed symbols) and perylene (open symbols) at $0^{\circ} \mathrm{C}$, as a function of preincubation temperature. and $\bigcirc: H D ; \triangle$ and $\triangle$ : control.

spectra, or in the influence of preincubation temperature on relative fluorescence intensity.

Sodium dodecyl sulfate polyacrylamide gel electrophoresis of membrane proteins and isoelectric focusing of purified spectrin from Huntington's disease red blood cells yielded normal patterns. This was also the case in studies on membrane protein phosphorylation. Finally, the results of $\left(\mathrm{Na}^{+}+\mathrm{K}^{+}\right)$- and $\mathrm{Mg}^{2+}$-ATPase assays are summarised in table 2. Again, no significant differences were found between controls and blood samples obtained from patients with Huntington's disease.
Table $2\left(\mathrm{Na}^{+}+\mathrm{K}^{+}\right)$- and $\mathrm{Mg}^{2+}-$ ATPase activity of control and HD ghost samples, in $\mu \mathrm{molPi} / \mathrm{mg}$ protein $h$

\begin{tabular}{lll}
\hline & $H D$ & Control \\
\hline $\mathrm{Mg}^{2+}+$ ATPase & $0.41 \pm 0.07(\mathrm{n}=12)$ & $0.41 \pm 0.09(\mathrm{n}=12)$ \\
$\left(\mathrm{Na}^{+}+\mathrm{K}^{+}\right)$-ATPase & $0.25 \pm 0.07(\mathrm{n}=12)$ & $0.22 \pm 0.04(\mathrm{n}=12)$ \\
\hline
\end{tabular}

\section{Discussion}

In the present investigations several aspects of red blood cell membrane structure and function have been studied in patients with Huntington's disease. Much attention was paid to appropriate standardisation of all procedures in handling the blood samples and in the various measurements. Cell deformability can be measured with several techniques, including viscosity measurements of concentrated cell suspensions and red cell filtration. Although in previous studies no discrepancies were detected when using viscosity measurements and cell filtration in parallel experiments (see for example reference 17) we prefer the viscosity technique. Using this method, cell deformability is measured at different, well-defined shear rates and thus this technique potentially yields more detailed information.

For cell deformability and $\left(\mathrm{Na}^{+}+\mathrm{K}^{+}\right)$ATPase activity, normal values were found. These results contradict reports in recent literature which claim decreased deformability ${ }^{2}$ and increased $\left(\mathrm{Na}^{+}+\mathrm{K}^{+}\right)$ ATPase activity ${ }^{3}$ in HD red blood cells. The reasons for these descrepancies remain as yet obscure.

Fluorescent spectroscopy is a very sensitive technique to detect changes in membrane structure. ${ }^{18-20}$ Moreover, in a recent report differences in fluorescence of ANS-labelled normal and Huntington's disease fibroblasts have been described. ${ }^{6}$ For these reasons a study of red cell membranebound ANS and perylene fluorescence was performed. ANS and perylene fluorescence, measured as described in the methods section, report mainly on the protein part of human red cell membranes, as will be discussed in detail elsewhere. As shown in the results section, no differences were found between normal and HD red cell membranes with this technique.

In further attempts to confirm the suggested alterations in red blood cell membrane organisation in Huntington's disease, some other techniques were used. Rather small alterations might be reflected by changes of the susceptibility of the cells to hypertonic cryohaemolysis. ${ }^{821}$ Further, possible changes in membrane structure can be 
reflected very sensitively in changes of the critical breakdown voltage, as measured in dielectric haemolysis experiments. ${ }^{922}$ As shown in the results section, however, normal values were found for all parameters in red blood cells of patients with Huntington's disease. These investigations do not support the notion of a diffuse, generalised membrane defect in Huntington's disease. A similar conclusion was reached by Cassiman et al. ${ }^{22}$ In a detailed study these authors could detect no differences in the surface properties of normal and HD fibroblasts. In view of further studies on the biochemical aspects of Huntington's disease a critical re-evaluation of arguments in favour of and against the membrane hypothesis seems appropriate.

The authors acknowledge the co-operation of $\mathrm{Dr}$ $M$ Vegter van der Vlis and of the Dutch Huntington Lay Society. We thank Miss Karmi Christianse for her skilful technical assistance.

Part of this work was carried out under the auspices of the Netherlands Foundation for Biophysics and with financial aid from the Netherlands Organisation for the Advancement of Pure Research (ZWO).

\section{References}

1 Butterfield DA, Oeswein JQ, Markesbery WR. Electron spin resonance study of membrane protein alterations in erythrocytes in Huntington's disease. Nature 1977; 267:453-5.

2 Butterfield DA, Purdy MJ, Markesbery WR. Electron spin resonance, hematological and deformability studies of erythrocytes from patients with Huntington's disease. Biochim Biophys Acta 1979; 551:452-8.

3 Butterfield DA, Oeswein JQ, Prunty ME, Hisle KC, Markesbery WR. Increased sodium plus potassium adenosine triphosphatase activity in erythrocyte membranes in Huntington's disease. Ann Neurol 1978; 4:60-2.

4 Markesbery WR, Butterfield DA. Scanning electron microscopy studies of erythrocytes in Huntington's disease. Biochem Biophys Res Commun 1977; 78:560-4.

5 Kirk D, Parrington JM, Corney G, Bolt JMW. Anomalous Cellular proliferation in vitro associated with Huntington's disease. Hum Genet 1977; 36:143-54.

6 Pettegrew JW, Nichols JS, Stewart RM. Fluorescence spectroscopy on Huntington's fibroblasts. $J$ Neurochem 1979; 33:905-11.

7 Weed RI, LaCelle PL, Merrill EW. Metabolic dependence of red cell deformability. J Clin Invest 1969; 48:795-809.
8 Dubbelman TMAR, de Bruijne AW, Cristianse K, Van Steveninck, J. Hypertonic cryohemolysis of human red blood cells. J Membrane Biol 1979; 50:225-40.

9 Rieman F, Zimmermann U, Pilwat G. Release and uptake of haemoglobin and ions in red blood cells induced by dielectric breakdown. Biochim Biophys Acta 1975; 394:449-62.

10 Fairbanks G, Steck TL, Wallach DFH. Electrophoretic analysis of the major polypeptides of the human erythrocyte membrane. Biochemistry 1971; 10:2606-17.

11 Bennett V, Branton D. Selective association of spectrin with the cytoplasmic surface of human erythrocyte plasma membranes. $J$ Biol Chem 1977; 252:2753-63.

12 Boivin $\mathrm{P}$, Galand C. Isoelectric focusing of spectrin components in hereditary spherocytosis. Clin Chim Acta 1976; 71:165-71.

13 Hodson A, Pleasure D. Erythrocyte cationactivated adenosine triphosphatases in Duchenne muscular dystrophy. J Neurol Sci 1977; 32:361-9.

14 Hosey MM, Tao M. An analysis of the autophosphorylation of rabbit and human erythrocyte membranes. Biochemistry 1976; 15:1561-8.

15 Anker HS. A solubilizable acrylamide gel for electrophoresis. FEBS Letters 1970; 7:293.

16 Burton AC. Role of geometry, of size and shape in the microcirculation. Fed Proc 1966; 25:175360.

17 Van Gastel LFJ, Van Steveninck J, De Bruijne AW. The influence of anesthetics on red cell deformability. Biochem Biophys Res Commun 1973; 55:1240-5.

18 Radda GK, Vanderkooi J. Can fluorescent probes tell us anything about membranes? Biochim Biophys Acta 1971; 265:509-49.

19 Mély-Goubert B, Freedman MH. Membrane associated proteins and malignancy: an experimental hypothesis. Cancer Biochem Biophys 1980; 4:167-171.

20 Mély-Goubert B, Freedman MH. Lipid fluidity and membrane protein monitoring using 1,6diphenyl-1,3,5-hexatriene. Biochim Biophys Acta 1980; 601:315-27.

21 Green FA, Jung CY. Cold-induced hemolysis in a hypertonic milieu. J Membrane Biol 1977; 33: $249-62$.

22 Pilwat G, Zimmermann U, Riemann F. Dielectric breakdown measurements of human and bovine erythrocyte membranes using benzyl alcohol as a probe molecule. Biochim Biophy Acta 1975; 406: 424-32.

23 Cassiman JJ, Verlinden J, Vlietinck RF et al. Qualitative and quantitative study of the growth and cell surface properties of Huntington's disease fibroblasts and age-matched controls. Lack of significant differences. Hum Genet 1979; 53:7586. 